\title{
Simulation of the Rainfall Regime over Ghana from CORDEX
}

\author{
Kwadwo Owusu ${ }^{1}$, Nana Ama Browne Klutse ${ }^{2}$ \\ ${ }^{1}$ Department of Geography and Resource Development, University of Ghana, Accra, Ghana \\ ${ }^{2}$ Ghana Space Science and Technology Center, Ghana Atomic Energy Commission, Accra, Ghana \\ Email: kowusu1@gmail.com, amabrowne@gmail.com
}

Received December 9, 2012; revised February 22, 2013; accepted March 18, 2013

Copyright (C) 2013 Kwadwo Owusu, Nana Ama Browne Klutse. This is an open access article distributed under the Creative Commons Attribution License, which permits unrestricted use, distribution, and reproduction in any medium, provided the original work is properly cited.

\begin{abstract}
This paper investigates how well the rainfall regime on which many livelihoods depend, in Ghana is well represented by the Coordinated Regional Climate Downscaling Experiment (CORDEX). The objective of the study is to demonstrate how well the ten CORDEX models are able to capture the spatial and temporal rainfall seasonality over the southern and northern sub-sections of Ghana. The choice of the sub-sections is based on the fact that south of $8^{\circ} \mathrm{N}$ experiences a bi-modal rainfall regime while the north has a uni-modal regime. The results indicate that the rainfall over Ghana is associated with high levels of variability at the inter-annual time scale. Particularly over the southern part of Ghana, all the models follow the same trend as represented over Ghana with similar rainfall values as the observation. Over the northern part of Ghana, models record relatively low rainfall agreeing with the observation. However, most of the models overestimate the northern region rainfall as it is in the case of the southern Ghana. CORDEX as shown in this analysis could be useful in providing Ghana with at least 10 different model outputs for impact analysis. Caution is however given that, since individual models give different performance and the fact that models in general have their inherent deficiencies, an ensemble mean of the models could provide a better result.
\end{abstract}

Keywords: CORDEX; Rainfall Modelling; Climate Change; Climate Variability; Climate Prediction; Ghana

\section{Introduction}

Africa's contribution to global climate change problem is only estimated to be between $2 \%$ to $4 \%$ [1], although the continent stands to suffer the most from the impacts of climate change [2]. This is as a result of climatic and non-climate factors that affect the economies of subSaharan African (SSA) countries. For example, SSA countries are located within the lower latitudes and therefore their agriculture is vulnerable to a changing climate of an increasing temperature that are likely to offset any precipitation increases through enhanced evapotranspiration [3]. The economies are also overly dependent on climate sensitive sectors like agriculture, energy and eco-tourism, which have fundamental problems like low mechanization and lack of infrastructure. In view of this, climate knowledge especially the ability to predict the future climate would go a long way to help Africa's economic development and improving livelihoods. Despite the need for climate information for development in SSA, the region lags behind every part of the world in terms of expertise in climate science [4,5], especially in the area of long term prediction [6]. Lack of climate data [7], low wages and loss of climatologist to Europe and North America are often cited as some of the problems that have created the low pool of expertise in Africa. In many parts of the continent, meteorological networks are hugely under-funded and are in the state of deterioration. The networks are generally sparse and often report meteorological data with significant delays [8]. The network coverage over Africa has a density of just one per 26,000 $\mathrm{km}^{2}$ which is eight times lower than the World Meteorological Organization (WMO) minimum recommended level [9]. In addition, there are very few universities actively involved in climate research in Africa, and their capacities are very limited [5]. According to [10] as quoted by Owusu et al. (in press), modelling capacity, be it a General Circulation Model (GCM) or a downscaled model, is highly lacking in Africa such that many modellers tend to rely on only one model output for their analysis.

Due to the lack of capacity, rainfall modelling in Af- 
rica is limited beyond South Africa and North Africa. In Ghana very little has been done in terms of climate modelling. However the economy of the nation depends highly on climate sensitive sectors like agriculture and hydro-electricity supply. For instance, agricultural contribution to Gross Domestic Product (GDP) is around $30 \%$, although it employs over $50 \%$ of the labour force [11]. The Akosombo and Akuse hydro plants on the Volta river supply over $70 \%$ of Ghana's electricity needs [12] with a new dam near completion on the Black Volta. There is the need to develop models that can clearly represent rainfall and its characteristics for impact assessment on such dams in order to minimise Ghana's vulnerability to climate change and its associated weather extremes. For the purpose of water resource management in Ghana and especially for rain-fed agriculture, it is also important to examine rainfall properties such as spatial distribution and seasonality.

The Coordinated Regional Climate Downscaling Experiment (CORDEX) which aims among other things at providing regional climate scenarios for impact assessment is also filling the gap of the lack of local capacity in many regions in Africa. However, for individual nations to fully benefit from the CORDEX output, that nation's climate should be well represented by the CORDEX models. This paper therefore investigates at the very basic level, how well the rainfall regime of which many livelihoods depend on, in Ghana is well represented by CORDEX. The objective is to demonstrate how well the ten CORDEX models are able to capture the spatial and temporal rainfall seasonality over the southern and northern sub-sections of Ghana at Latitude $8^{\circ} \mathrm{N}$ partition. This partition is based on the fact that south of $8^{\circ} \mathrm{N}$ experiences a bi-modal rainfall regime while the north has a uni-modal regime $[13,14]$. The rainfall over the West African region and Ghana is associated with high levels of variability at the interannual and most importantly at the multi-decadal scale [15]. It is therefore important for models simulating rainfall over the sub-region to be able to capture both the regimes and variability.

\section{Study Area}

The study focuses on the Republic of Ghana which for the purpose of this work is defined within latitudes $4.5^{\circ} \mathrm{N}$ to $11.5^{\circ} \mathrm{N}$ and Longitudes $2.5^{\circ} \mathrm{W}$ and $0.5^{\circ} \mathrm{E}$. The country is divided into a Southern zone below latitude $8^{\circ} \mathrm{N}$ and Northern zone above the same latitude (Figure 1). The Southern zone is characterised by a bi-modal rainfall regime with a major rainy season from late March to early July and a minor rainy season from late August to November [16]. Between the two rainy seasons is a welldefined short dry season which is important for agricultural purposes in terms of minimizing post-harvest losses and also helps land preparation for the minor season

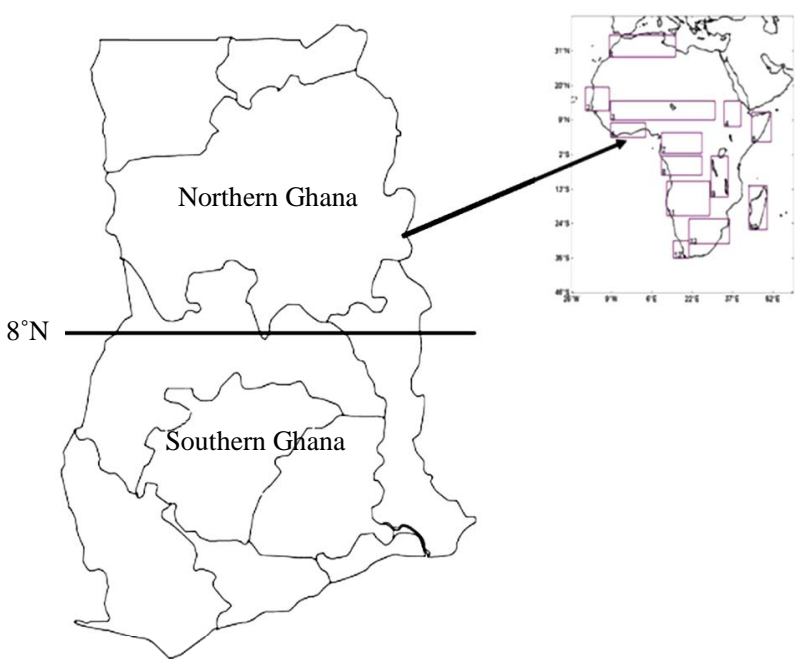

Figure 1. CORDEX Africa domain and study area.

crops [15]. The Northern zone has a uni-modal regime with the rains starting in June and ending in October. This gives rise to a single crop production in a season under the rainfed agriculture practiced in the zone. The long dry season known in West Africa as Harmattan follows the end of the rains in both zones of the country.

The dominant climate systems that drive the rainfall regimes are the Inter-Tropical Convergent Zone (ITCZ) and its associated North-East and South-West seasonal winds called the monsoon [17,18]. Other important drivers are the African Easterly Waves (AEWs) and Tropical Easterly Jets (TEJs). The El Nino Southern Oscillation phenomena and changes in the Atlantic Sea Surface Temperatures (SSTs) have also been identified by [13-19] as significantly contributing to interannual rainfall variability over Ghana.

For instance, it is noted that a warm SSTs induces more rainfall whilst the reverse causes reduced rainfall in the southern half of Ghana [13]. Additionally, the warm phase of the El Nino is associated with reduced rainfall whilst La Nina is associated with more rainfall over Ghana [16].

\section{Data and Methods}

This study used ten available models from the Coordinated Regional Climate Downscaling Experiment-CORDEX [20-22]. The Regional Climate Model (RCM) simulations were performed at various institutions indicated in Table 1. Table 1 also contains the list of the RCMs, their short names and used in the study. Most of the simulations are on the same rotated grid with $0.44^{\circ}$ horizontal resolution and all data sets on other grids are remapped to this reference grid. In the experiments, as documented in [20-22], each RCM simulation is forced on the lateral boundary with the third generation ECMWF reanalysis product, ERA-Interim [23]. 
Table 1. List of RCMs and their institutions.

\begin{tabular}{|c|c|c|}
\hline RCM & Short name & Institution \\
\hline CNRM-ARPEGE5.1 & AEPEGE & $\begin{array}{l}\text { Center National de Recherches } \\
\text { Meteorologiques, France }\end{array}$ \\
\hline DMI-HIRHAM5 & HIRHAM & $\begin{array}{l}\text { Denmarks Meteorologiske } \\
\text { Institut, Danmark }\end{array}$ \\
\hline ICTP-REGCM3 & RegCM3 & $\begin{array}{l}\text { Abdus Salam International Center } \\
\text { for Theoretical Physics, Italy }\end{array}$ \\
\hline CLMcom-CCLM4.8 & CCLM & $\begin{array}{c}\text { CLM Community } \\
\text { (www.clm-community.eu) }\end{array}$ \\
\hline KNMI-RACMO2.b & RACMO & $\begin{array}{l}\text { Koninklijk Nederlands } \\
\text { Meteorologisch Instituut, } \\
\text { The Netherlands }\end{array}$ \\
\hline MPI-REMO & REMO & Max Planck Institute, Germany \\
\hline SMHI-RCA35 & RCA & $\begin{array}{l}\text { Sverigies Meteorologiska och } \\
\text { Hydrologiska Institut, Sweden }\end{array}$ \\
\hline UCT-PRECIS & PRECIS & $\begin{array}{l}\text { University of Cape Town, } \\
\text { South Africa }\end{array}$ \\
\hline UC-WRF3.1.1 & WRF & Universidad de Cantabria, Spain \\
\hline UQAM-CRCM5 & CRCM & $\begin{array}{l}\text { Univerite du Quebee a } \\
\text { Montreal, Canada }\end{array}$ \\
\hline
\end{tabular}

The simulations are done for the present day climate (1989-2008) and carried out at a resolution of about 50 $\mathrm{km}$ over a predefined CORDEX Africa domain (Figure 1). Eight of the ten RCMs employ the ERA-Interim Sea Surface Temperature (SST) for ocean boundary conditions. The ICTP-RegCM uses the NOAA weekly optimum interpolation SST while CRCM uses the AMIP2 SST. We use UDEL (1998-2010) satellite-gauge combination [24] for model comparison.

The rainfall climatology over Ghana is defined here as the average rainfall in June-July-August-September (JJAS) for 1989 to 2008 inclusive. The months for the raining seasons is chosen strategically to cover the raining seasons of both southern and northern Ghana delineated at Latitude $8^{\circ} \mathrm{N}$. The Hovemuler diagram presents a Time-Latitude plot showing the interseasonal rainfall over Ghana averaged between 3W and 1E. The interannual rainfall variation is averaged over $4.2 \mathrm{~N}$ to $11.5 \mathrm{~N}$ and $3 \mathrm{~W}$ to $1 \mathrm{E}$.

\section{Results}

The mean state of the JJAS rainfall over Ghana for 19892008 period is shown in Figure 2. The models agree reasonably well in terms of the spatial distribution of the mean rainfall. Simulated rainfall climatologies of JJAS are generally consistent with observations for all models except for CNRM-ARPEGE and CCLMcom-CCLM. The models generally capture the spatial variability of rainfall with maxima well represented over the northern part of
Ghana. In particular, the regional models are consistent in showing that rainfall is low over the southern part of Ghana. However, CCLMcom-CCLM shows its minimum rainfall of an amount below $1 \mathrm{~mm} /$ day over the middle part of Ghana and CNRM-ARPEGE shows a uniform spatial rainfall over the country.

The latitudinal shift in rainfall over Ghana is demonstrated with a time-latitude diagram shown in Figure 3. The figure presents a picture of the West African monsoon jump. From the figure, all the models except the CNRM-ARPEGE depict the two peaks of the raining season of the southern part and the single peak of rainfall of the northern part of Ghana well.

The interannual cycle of rainfall pattern over Ghana (Figure 4) is well reproduced by most of the models though with different values between 2.5 and $5.0 \mathrm{~mm} /$ day. The models peak at wet years and have low values during dry years. All models except DMI agreed with observation that 1999 was a wet year. However, most of the models missed the peak of 1995. In all, the models except CLMcom-CCLM and KNMI-RACMO overestimate rainfall throughout the years and DMI-HIRHAM shows higher values.

For more information on rainfall characteristics, the study area is divided into two climatic zones, the northern and the southern Ghana. Over the southern part of Ghana (Figure 5), the models follow the same trend of interannual rainfall as it is over Ghana with similar rainfall values of the models and observation. The northern part of Ghana records relatively low rainfall. Most of the models overestimate the northern region rainfall (Figure 6) as it is in the case of the southern Ghana. Both CLMcom-CCLM and KNMI-RACMO underestimate the rainfall in most years but CLMcom-CCLM shows much lower rainfall values of below $2.2 \mathrm{~mm}$ /day throughout the years.

\section{Discussion}

The models capture the interannual variability in the observation reasonably well. As known over Ghana, the rainfall range is between 1 and $14 \mathrm{~mm} /$ day as the models indicate and also southern part is mostly dry in comparison to the northern part of Ghana. However, the climatological map provides only less information. In Figure 3 where the inter-seasonal rainfall is shown with a Hovemuler plot, the monsoon jump is clearly shown by all the models as known over West Africa in July/August [25]. The two rainfall peaks in the southern part of Ghana are well represented as observed. Past studies have shown that the general inter-annual rainfall over Ghana in the period of 1950 to 2000 discuss that the mean rainfall over the last 20 years (1980-2000) has declined in relation to the past 20 years spanning 1950-1970. The period between 1971 to 1979 stayed between the high and the 


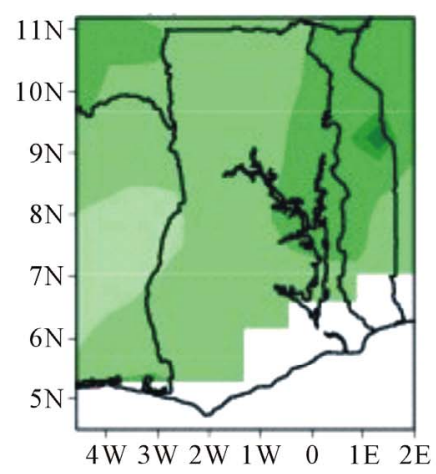

(a)

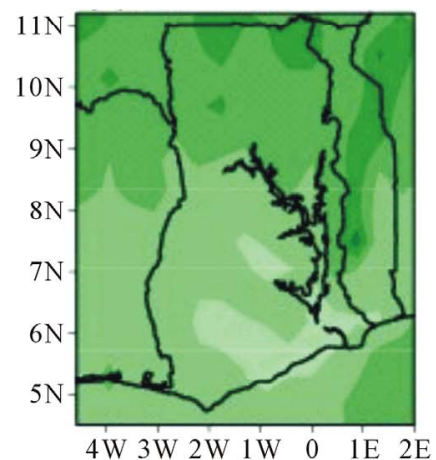

(d)

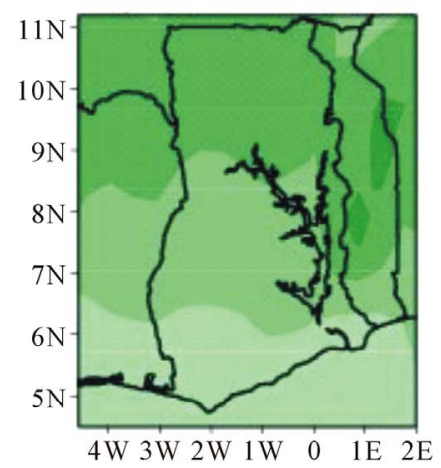

(g)

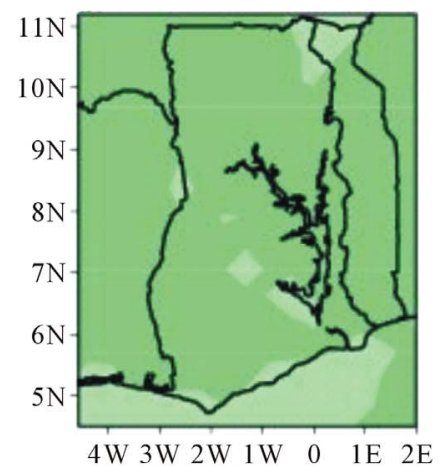

(j)

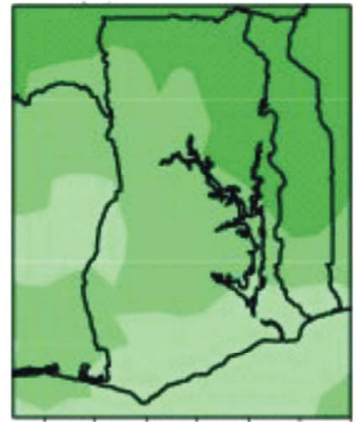

$4 \mathrm{~W} 3 \mathrm{~W} 2 \mathrm{~W} \quad 1 \mathrm{~W} \quad 0 \quad 1 \mathrm{E} \quad 2 \mathrm{E}$

(b)

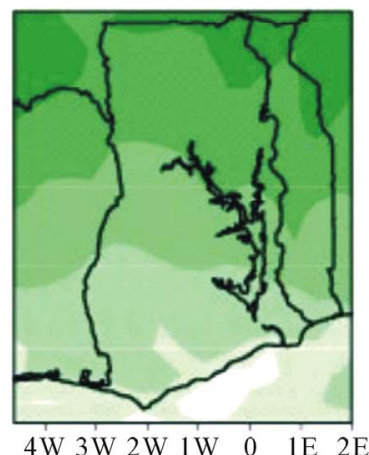

(e)

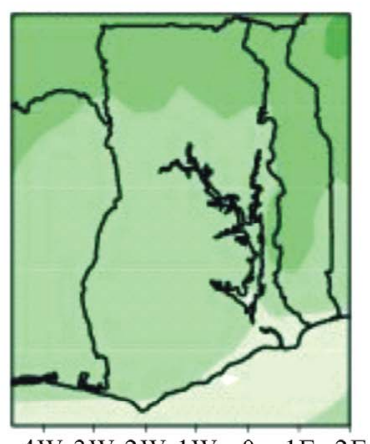

4W 3 W 2 W $1 \mathrm{~W} \quad 0 \quad 1 \mathrm{E} 2 \mathrm{E}$

(h)

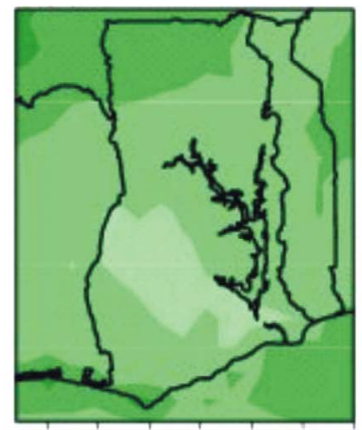

$4 \mathrm{~W} 3 \mathrm{~W} 2 \mathrm{~W} \quad 1 \mathrm{~W} \quad 0 \quad 1 \mathrm{E} \quad 2 \mathrm{E}$

(k)

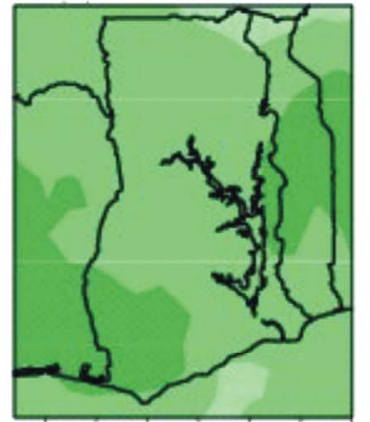

$4 \mathrm{~W} 3 \mathrm{~W} 2 \mathrm{~W} 1 \mathrm{~W} \quad 0 \quad 1 \mathrm{E} \quad 2 \mathrm{E}$

(c)

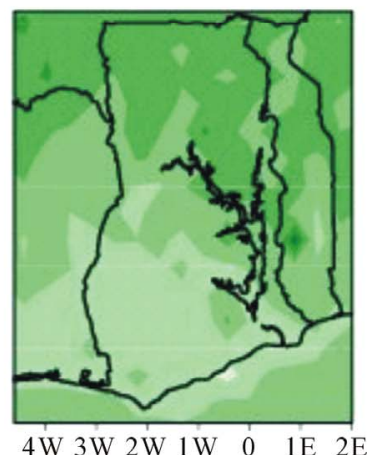

(f)

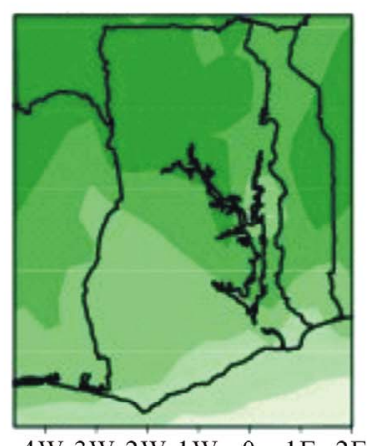

(i)

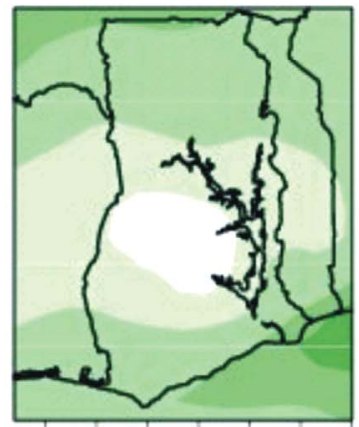

$4 \mathrm{~W} 3 \mathrm{~W} 2 \mathrm{~W} \quad 1 \mathrm{~W} \quad 0 \quad 1 \mathrm{E} \quad 2 \mathrm{E}$

(1)

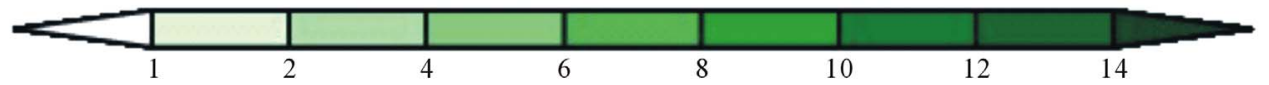

Figure 2. Rainfall climatology over Ghana from CORDEX models. (a) UDEL JJAS; (b) TRMM JJAS; (c) ERA-INT JJAS; (d) DMI-HIRHAM JJAS; (e) ICTP-REGCM JJAS; (f) UCT-PRECIS JJAS; (g) SMHI-RCA JJAS; (h) KNMI-RACMO JJAS; (i) UC-WRF JJAS; (j) CNRM-ARPEGE JJAS; (k) MPI-REMO JJAS; (l) CCLMCOm-CCLM JJAS. 


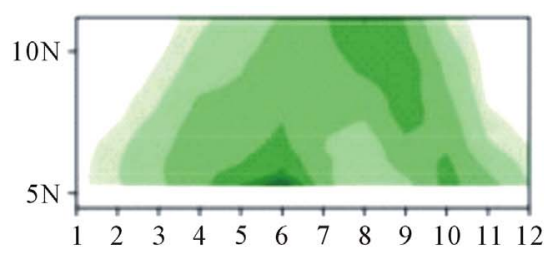

(a)

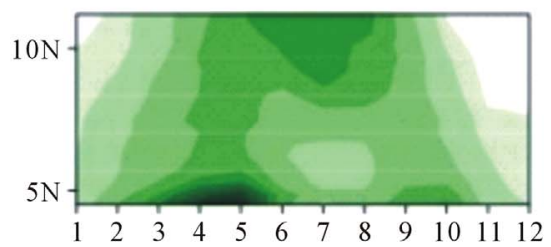

(d)

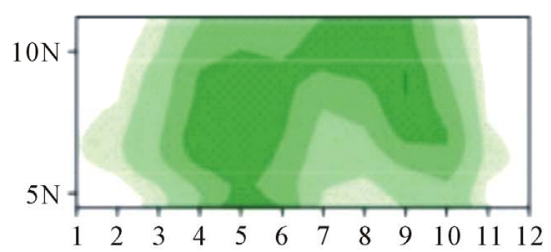

(g)

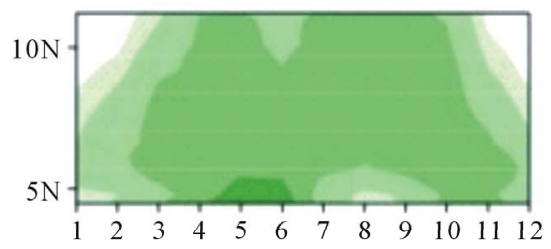

(j)

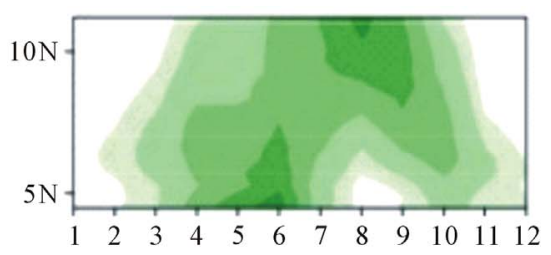

(b)

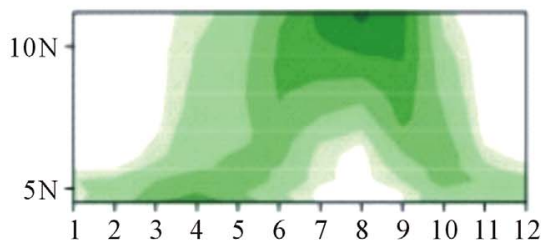

(e)

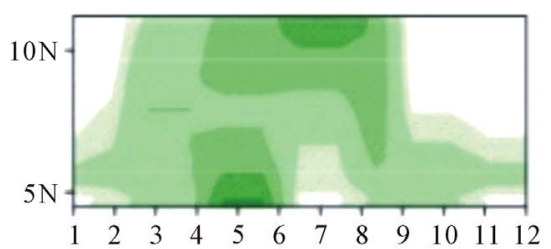

(h)

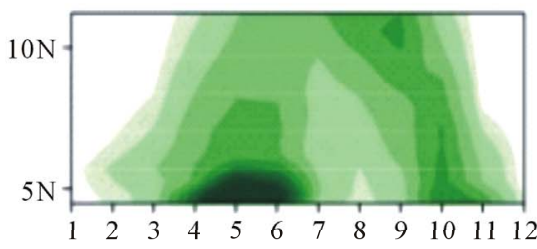

(k)

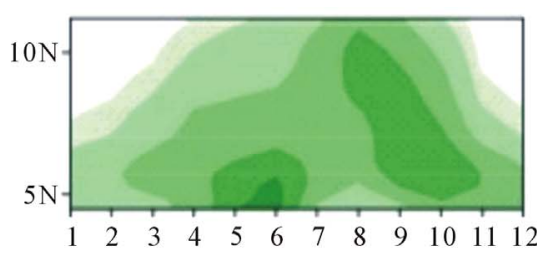

(c)

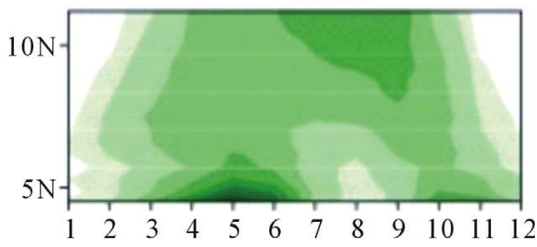

(I)

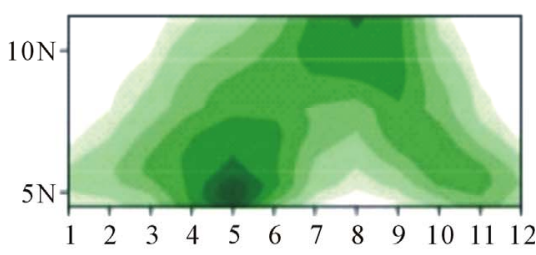

(i)

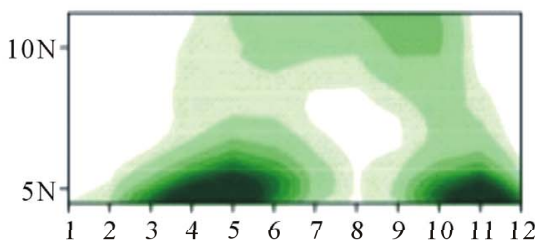

(1)

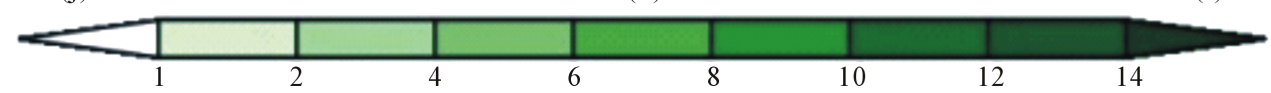

Figure 3. Latitude-Time plot showing the inter-seasonal rainfall over Ghana (3W-1E). (a) UDEL; (b) TRMM; (c) ERA-INT; (d) DMI-HIRHAM; (e) ICTP-REGCM; (f) UCT-PRECIS; (g) SMHI-RCA; (h) KNMI-RACMO; (i) UC-WRF; (j) CNRMARPEGE; (k) MPI-REMO; (l) CCLMCOm-CCLM.

Inter-annual Rainfall over Ghana

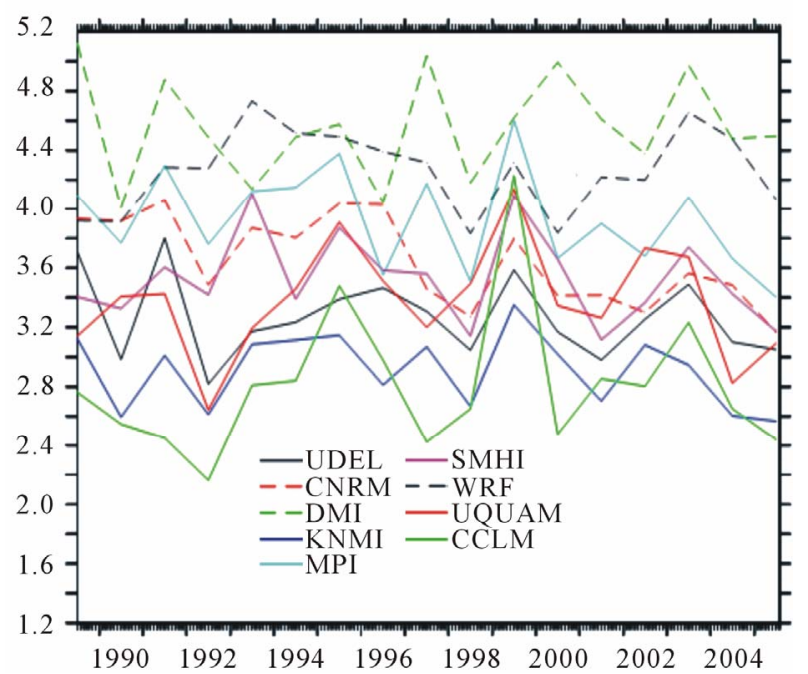

Figure 4. Inter-annual rainfall over Ghana.
Inter-annual Rainfall over Southern Ghana

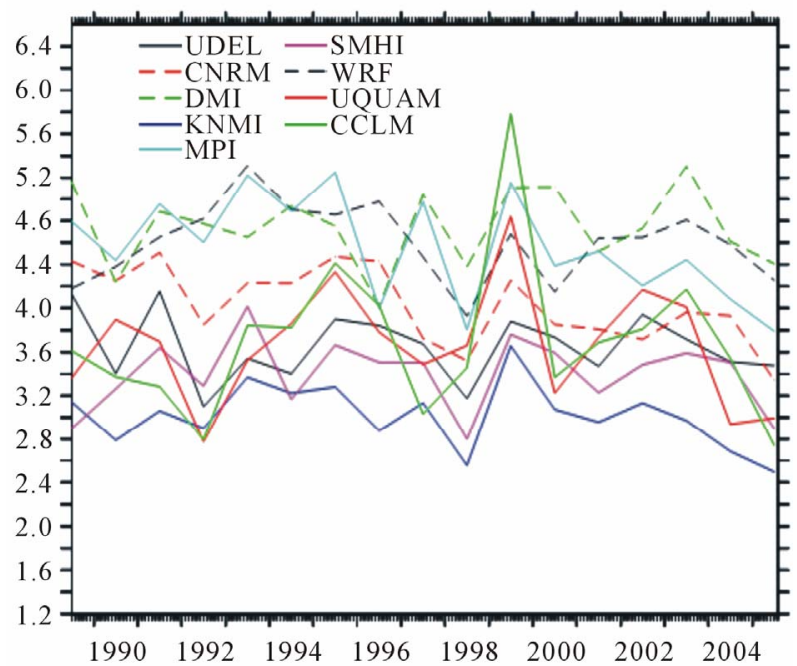

Figure 5. Inter-annual rainfall over southern Ghana. 


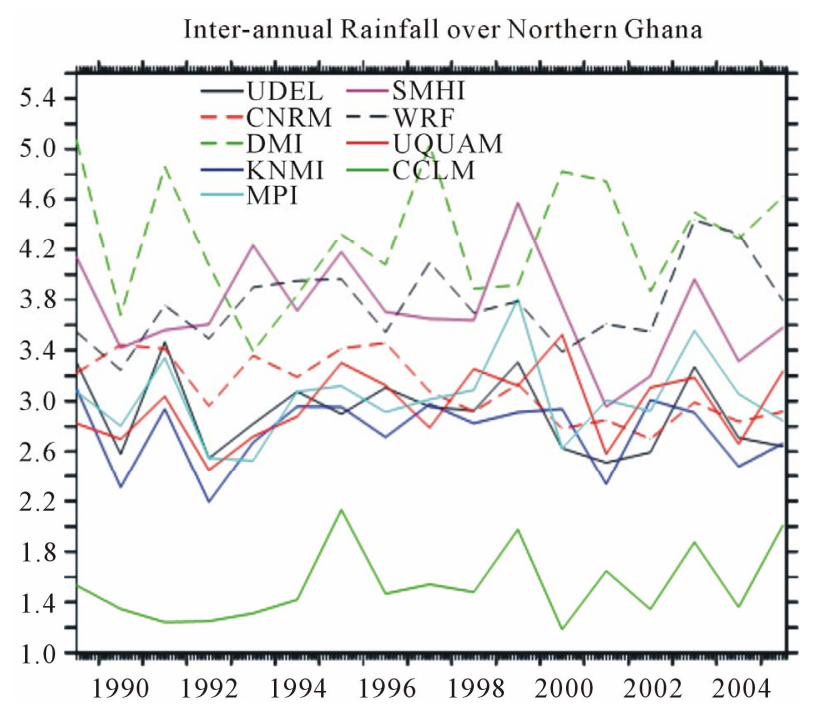

Figure 6. Inter-annual rainfall over northern Ghana.

low means [14].

The available period of the simulation is 1989 to 2008 . The pattern discussed above is not clearly shown by the models probably because of the length of the data shown. Information from observed station data over southern part and the northern part of Ghana for the exact period of the simulation supports the augment that most of the models are representing the rainfall characteristics of Ghana.

\section{Conclusion}

In all, the simulations analyzed here show that the RCMs reproduce fairly well the rainfall characteristics but exhibit different deficiencies and show mixed results in terms of outperforming the driving field, indicating a substantial sensitivity of RCMs to regional and local processes. This confirms the need to use multi-model ensemble approach to cover the range of uncertainties over Ghana as accepted in the CORDEX Africa project. CORDEX as shown in this analysis could be useful in providing Ghana with at least 10 different model outputs for impact analysis. The models performances suggest that they may be useful for decision making for the sectors like agriculture and water management. Caution is however given that since individual models give different performance and the fact that models in general have their inherent deficiencies an ensemble mean of the models could provide a better result.

\section{REFERENCES}

[1] H. Ahlenius, "Emissions of Carbon Dioxide, in Africa and Selected OECD Countries," UNDP/GRID Arendal, 2006.

http://www.grida.no/graphicslib/detail/emissions-of-carbo n-dioxide-in-africa-and-selected-oecd-countries_1400

[2] IPCC, "Climate Change 2007 Synthesis Report. Contribution of Working Groups I, II and III to the Fourth Assessment Report of the Intergovernmental Panel on Climate Change,” IPCC, Geneva, 2007.

[3] J. Verdin, C. Funk, G. Senay and R. Choularton, "Climate Science and Famine Early Warning," Philosophical Transactions of the Royal Society B, Vol. 360, No. 1463, 2005, pp. 2155-2168. doi:10.1098/rstb.2005.1754

[4] R. Washington, G. Kay, M. Harrison, D. Conway, E. Black, A. Challinor, D. Grimes, R. Jones, A. Morse and M. Todd, "African Climate Change: Taking the Shorter Route," Bulletin of the American Meteorological Society, Vol. 87, No. 10, 2006, pp. 1355-1366. doi:10.1175/BAMS-87-10-1355

[5] UNECA, "Climate Science, Information, and Services in Africa: Status, Gaps and Policy Implications,” Working Paper 1, 2011.

http://www.uneca.org/acpc/about_acpc/policy_documents /papers/WP1Climate\%20Science\%20data\%20and\%20inf o\%20formated\%20draft\%20final.pdf

[6] UNFCCC, "Background Paper on Impacts, Vulnerability and Adaptation to Climate Change in Africa for the African Workshop on Adaptation: Implementation of Decision," UNFCCC Convention, Accra, 21-23 September 2006.

[7] M. Kadi, L. N. Njau, J. Mwikya and A. Kamga, "The State of Climate Information Services for Agriculture and Food Security in West African Countries,” CCAFS Working Paper No. 4, Copenhagen, 2011.

[8] R. Washington, M. Harrison and D. Conway, "African Climate Report,” University of Oxford, Oxford, 2004. http://www.eldis.org/static/DOC16980.htm

[9] WMO, “Twenty-First Status Report on Implementation of the World Weather Watch: Forty Years of World Weather Watch,” WMO Report 957, 2003.

[10] G. Ziervogel, et al., "Climate Change and Adaptation in African Agriculture,” SEI, Oxford, 2008.

[11] ISSER, "The State of the Ghanaian Economy in 2010," ISSER, University of Ghana, Accra, 2011.

[12] J. Jones, "Capacity of African National Meteorological and Hydrological Services,” Report Prepared at the Request of for World Bank, 2010.

[13] Y. Opoku-Ankomah and I. Cordrey, "Atlantic Sea Surface Temperatures and Rainfall Variability in Ghana” Journal of Climate, Vol. 7, No. 4, 1994, pp. 551-558. doi:10.1175/1520-0442(1994)007<0551:ASSTAR >2.0.C O;2

[14] K. Owusu and P. R. Waylen, "Trends in Spatio-Temporal Rainfall Variability in Ghana, (1951-2000),” Weather, Vol. 64, No. 5, 2009, pp. 115-120

[15] K. Owusu and P. Waylen, "The Changing Rainy Season Climatology of Mid-Ghana," Theoretical and Applied Climatology, Vol. 2012, 2012, pp. 1-12. doi:10.1007/s00704-012-0736-5

[16] K. Owusu, P. R. Waylen and Y. Qui, “Changing Rainfall Inputs in the Volta Basin: Implications for Water Sharing 
in Ghana,” Geo Journal, Vol. 71, No. 4, 2008, pp. 201210.

[17] N. Zeng, "Drought in the Sahel,” Science, Vol. 302, No. 5647, 2003, pp. 999-1000. doi:10.1126/science.1090849

[18] S. Weldeab, D. W. Lea, R. R. Schneider and N. Andersen, "155,000 Years of West African Monsoon and Ocean Thermal Evolution,” Science, Vol. 316, 2007, pp. 13031307. doi:10.1126/science. 1140461

[19] P. Lamb and R. A. Peppier, "Further Case Studies of Tropical Atlantic Surface Atmospheric and Oceanic Patterns Associated with Sub-Saharan Drought," Journal of Climate, Vol. 5, No. 5, 1992, pp. 476-488. doi:10.1175/1520-0442(1992)005<0476:FCSOTA>2.0.C $\mathrm{O} ; 2$

[20] F. Giorgi, C, Jones and G. R. Asrar, "Addressing Climate Information Needs at the Regional Level: The CORDEX Framework," WMO Bulletin, Vol. 58, No. 3, 2009, pp. 175-183.

[21] C. Jones, F. Giorgi and G. Asrar, "The Coordinated Regional Downscaling Experiment: CORDEX, an International Downscaling Link to CMIP5,” Clivar Exchanges,
Vol. 16, 2011, pp. 34-39.

[22] J. P. Evans, "CORDEX-An International Climate Downscaling Initiative,” 2011.

[23] A. Simmons, S. Uppala, D. Dee and S. Kobayashi, "ERAInterim: New ECMWF Reanalysis Products from 1989 Onwards,” ECMWF Newsletter, Vol. 110, 2007, pp. 2535.

[24] G. J. Huffman, R. F. Adler, M. M., Morrissey, D. T. Bolvin, S. Curtis, R. Joyce and J. Susskind, "Global Precipitation at One-Degree Daily Resolution from Multisatellite Observations,” Journal of Hydrometeorology, Vol. 2, No. 1, 2001, pp. 36-50. doi:10.1175/1525-7541(2001)002<0036:GPAODD>2.0.C $\underline{\mathrm{O} ; 2}$

[25] M. B. Sylla, F. Giorgi, E. Coppola and L. Mariotti, “Uncertainties in Daily Rainfall over Africa: Assessment of Gridded Observation Products and Evaluation of a Regional Climate Model Simulation,” International Journal of Climatology, Vol. 33, No. 7, 2002, pp. 1805-1817. doi:10.1002/joc.3551 